\title{
DOES FRANCHISING CREATE VALUE? AN ANALYSIS OF THE FINANCIAL PERFORMANCE OF US PUBLIC RESTAURANT FIRMS*
}

\author{
E. Hachemi Aliouche, Ph.D. \\ Assistant Professor, School of Business \\ Southern New Hampshire University \\ Senior Research Fellow, \\ The William Rosenberg International Center of Franchising, \\ University of New Hampshire \\ Udo Schlentrich, Ph.D. \\ Associate Professor, Whittemore School of Business and Economics \\ University of New Hampshire \\ Director, \\ The William Rosenberg International Center of Franchising, \\ University of New Hampshire
}

Working Paper No. 2005-02

*This paper has been selected as the winner of the 2005 International Franchise Association Educational Foundation's Arthur Karp Research Award for "Best Applied Paper." 


\section{DOES FRANCHISING CREATE VALUE? AN ANALYSIS OF THE FINANCIAL PERFORMANCE OF US PUBLIC RESTAURANT FIRMS}

\section{Executive Summary:}

It is commonly believed that the franchising method of distribution provides strategic and operational benefits to the companies that adopt it. These benefits should result in superior financial performance as compared to that of firms that do not use franchising. Yet, the empirical evidence of the effects of franchising on financial performance is sparse and mixed. The purpose of this paper is to further examine the empirical evidence of the impact of franchising on a firm's financial performance by using performance metrics (Economic Value Added and Market Value Added) that are extensively used in corporate finance. This study focuses on the US public restaurant sector. The results provide some evidence that franchising firms create more market and economic value than do non-franchising firms.

Key words:

Franchising, Financial Performance, Restaurant Sector, Economic Value Added, Market Value Added. 


\section{DOES FRANCHISING CREATE VALUE? AN ANALYSIS OF THE FINANCIAL PERFORMANCE OF US PUBLIC RESTAURANT FIRMS}

\section{INTRODUCTION}

Franchising has grown so fast since the 1950s that it is now pervasive in the US economy. In a recent study commissioned by the International Franchise Association, PriceWaterhouseCoopers estimated that in 2001 there were more than 767,000 business establishments in the United States engaged in franchising, providing directly or indirectly more than 18 million jobs, over $\$ 506$ billion in payroll, and over $\$ 1.5$ trillion of output (PriceWaterhouseCoopers, 2004). Franchising now dominates certain sectors of the US economy. For example, over 56 percent of quick service restaurants are franchises (PriceWaterhouseCoopers, 2004). Franchising is also one of the fastest growing US exports (House Committee on Small Business, 1990), and it is now estimated that franchising (in terms of number of franchised units) will grow 12 to 14 percent per year in the future (Justis and Judd, 2003).

The US Department of Commerce has defined franchising as follows: "Franchising is a method of doing business by which a franchisee is granted the right to engage in offering, selling, or distributing goods or services under a marketing format which is designed by the franchisor. The franchisor permits the franchisee to use the franchisor's trademark, name, and advertising" (Kostecka, 1987, p. 2). Franchising has evolved over time and we can now distinguish two broad categories of franchising: product distribution franchising and business format franchising. Business format franchising consists of a continuing commercial relationship between a firm with a proven business system (the franchisor) and a third party (the franchisee), whereby the franchisor grants rights to the 
franchisee for a given period of time to operate their business system using a common brand and common format for promoting, managing, and administering this business. Examples of business format franchising are quick service restaurants (McDonalds, Burger King) and lodging (Marriott, Hilton). Product distribution franchising, on the other hand, is a more limited business relationship, whereby the franchisor grants the franchisee the right to use its trademark, but may not provide her/him with a system of running its business. Examples are automobile dealerships (Ford, Pontiac), and gas stations (Texaco, Shell). Business format franchising is now much more prevalent than product distribution franchising, with about 4.3 times as many establishments, and providing 4 times as many jobs in 2001 (PriceWaterhouseCoopers, 2004).

Given the success and popularity of franchising, it may seem evident that franchising helps firms achieve superior financial performance. The object of this paper is to investigate this proposition. First, the dominant theories explaining the motivation of firms to franchise (resource scarcity theory and agency theory) are summarized and their implications for financial performance assessed. Then the empirical studies addressing the financial performance of franchising firms are reviewed. Despite the undeniable popularity of franchising, there is surprisingly little empirical evidence that franchising delivers superior financial performance. Perhaps even more surprising, there are very few studies that have tried to assess the value that franchising brings to a firm.

In this paper we empirically investigate the hypothesis that franchising enhances a firm's financial performance through superior value creation. Building on previous studies, we propose a focused methodology and two measures of value creation that are extensively 
used in corporate finance. Based on four sets of indicators, we find some evidence that franchising systems create significantly more value in the US restaurant industry than non-franchising systems.

\section{WHY FRANCHISE?}

The rapid growth of franchising has attracted the interest of academic researchers with close to 100 articles in a variety of academic fields (economics, finance, management, marketing,...) having been published on this topic by the mid-1990s (Elango and Fried, 1997). Dozens more have been published since then. Of particular interest is the motivation for firms to franchise rather than to expand through company-owned units. The two dominant theories that explain the motivation for franchising are agency theory and resource scarcity theory. Given the purpose of this paper, it is useful to review these theories and their implications for franchisor performance.

\section{Agency theory}

A number of studies have explained the existence of franchising through agency theory (Fama and Jensen, 1983; Matheson and Winter, 1985; Brickley and Dark, 1987;

Lafontaine, 1992). An agency relationship exists whenever one party (the principal) hires an individual or an organization (the agent) to provide a service, and delegates decisionmaking authority to that agent.

Because the agent's and the principal's self-interests may not coincide, the potential for a 
conflict of interests exists. The agent may not always act in the principal's best interests (Jensen and Meckling, 1976; Eisenhardt, 1989). For example, potential shirking by the agent is a widely discussed problem in the franchise literature (Rubin, 1978; Brickley and Dark, 1987). A salaried manager may not always put forth his/her best effort and therefore may produce sub-optimal performance. In order to reduce this moral hazard, a non-franchised firm may need to institute a costly monitoring system. Franchising, on the other hand, addresses this problem by providing powerful incentives for the ownermanager of the franchised unit to perform well. For example, the owner-manager (i.e., the franchisee) has a direct claim to the residual profits of her/his unit. Also, because the franchisee has put her/his own capital at risk she/he has a powerful incentive to make her/his franchised unit successful (Brickley and Dark, 1987). Because franchising aligns the interests of the two parties (the franchisor and the franchisee), there is less need for monitoring and a greater probability for maximum performance by the franchisee (Bradach, 1997). There is evidence that increased managerial ownership did improve firm performance (Bruton, Keels and Scifres, 2002). Better performance by the franchisees should translate into improved performance by the franchisor, as the franchisor's performance depends to a large extent on its franchisees' performance.

\section{Resource scarcity theory:}

An alternative theory explains franchising as a solution to the capital, managerial and informational constraints faced by expanding firms (Oxenfeldt and Kelly, 1968; Caves and Murphy, 1976; Norton, 1988; Carney and Gedajlovic, 1991; Shane, 1996). This theory argues that expanding firms use franchising to get access to scarce capital (the 
franchisee's capital) in a cost effective way. John Y. Brown, the former president of Kentucky Fried Chicken, estimated that it would have cost KFC $\$ 450$ million to establish its first 2,700 stores, an amount of capital that was not available to KCF in the early stages of its expansion (Tikoo, 1996).

A young expanding firm has two options to secure the capital it needs: sell equity or sell franchises. A third option, selling debt, may not be a possibility in the early stages of a firm's existence as it may lack collateral and a proven track record. Selling franchises may therefore be the more cost effective and realistic option (Dant, Kaufmann, 2003). Furthermore, franchisees may be able to provide capital to the franchisor at a lower cost than passive investors can (Combs and Kitchen, 1999a). In addition to capital, franchising also provides an efficient way to obtain the managerial expertise needed to grow the business. Because a franchisee puts a significant amount of her/his assets and time into her/his unit, she/he is likely to purchase a franchise only if she/he is confident in her/his managerial abilities (Shane, 1996). Thus franchising addresses the adverse selection problem of firms hiring managers who may overstate their qualifications to secure employment. Franchising also allows a firm to leverage the local market knowledge of its franchisees as it expands into new geographic areas (Minkler, 1990).

Low cost capital, motivated managerial expertise, and better local market knowledge are three key resources that should reduce a franchisor's overall risk and have a significant positive impact on a franchisor's financial performance. 


\section{FRANCHISING PERFORMANCE}

The real value of franchising to a firm is the improvement in business performance due to its choice of growing through franchising instead of growing through its own means.

Despite the large body of literature on franchising, only a handful of studies have addressed the effects of franchising on a firm's performance. The evidence presented by the few studies that have addressed this issue is mixed.

Leleux, Spinelli, and Birley (2003) contrasted the financial performance of the US public franchisors to the Standard and Poors 500 index performance. They concluded that the US public franchisors outperformed the S\&P 500 (higher cumulative shareholder returns at similar average risk levels) for nine of the ten years of their study. Michael (2002) found that franchising helped firms gain market share and, consequently, improved their financial performance. Using return on equity (ROE) as their performance metric and narrowing the scope of their study, Alon, Drtina, and Gilbert (2004) examined the financial performance of franchising versus non-franchising firms in the restaurant sector over a one-year period. They concluded that franchising did not provide any sustainable profit benefit for franchised firms in the restaurant sector. Finally, Combs and Ketchen (1999b) could not find a linear relationship between franchising and performance.

In this study we examine the effects of franchising on a firm's financial performance by developing a methodology that takes into account the recommendations for improvement of the previous studies, and by using new performance metrics recently developed and employed in corporate finance. We improve on previous studies in the following three 
aspects:

1. Use ten years of data (1993-2002). A one-year performance measurement may not be representative of the true performance of a firm, as a firm may have a stellar performance one year and awful results another year (Collins, 2001). The results obtained may depend highly on what year was chosen for the analysis. In addition, one period accounting numbers (earnings, “one-time” charges, inventories, etc.) are notoriously subject to manipulation (BusinessWeek, October 4, 2004). A ten-year average smoothes the influence of transitory events, and provides a metric that is much closer to the true performance of the firm. Alon, et al. (2004) suggest the use of multi-year data to further study the impact of franchising on profitability.

2. Focus on a homogeneous and important segment of the franchising universe. Because different franchising industries have different characteristics, Dant et al. (1996), Elango and Fried (1997), Alon (1999), and Alon et al. (2004) have suggested that studies focus on particular industries. Dant and Kaufmann (2003) have suggested that a focus on a single sector may enhance the "internal validity of the investigation." We focus on the restaurant sector because franchising is very important in this sector, and this sector is one of the few franchising industries with enough public firms to provide a meaningful sample for empirical analysis.

3. Use improved performance metrics. A major problem with traditional financial performance metrics such as return on equity (ROE) and return on assets (ROA) is that 
they lack a formal link to shareholder value. They do not explicitly take into account risk, and they do not reflect the opportunity cost of the capital used. The metrics we propose, economic value added (EVA) and market value added (MVA), address these shortcomings.

In corporate finance, it is assumed that management's primary responsibility is to maximize shareholder value (Brigham and Houston, 2004). It is generally recognized that potential agency problems exist in public firms (Jensen and Meckling, 1976). However, managers can be motivated to act in the shareholders' best interests through incentives that reward good performance and punish poor performance. These incentives may include, for example, managerial compensation that is tied to shareholder value, direct intervention by shareholders, the threat of firing or the threat of hostile takeover. According to OECD's Business Sector Advisory Group on Corporate Governance, in most industrialized societies, "the generation of long-term economic profit to enhance shareholder value" is recognized as the corporation's primary objective (OECD, 1998). Shareholder value depends on return, risk, and the amount of capital invested. As we mentioned above, a major problem with ROE and other traditional financial performance metrics is that they may not be consistent with shareholder value maximization. On the other hand, EVA and MVA are consistent with shareholder value maximization. Over the past decade, EVA and MVA have become very popular with US corporations. 


\section{Economic Value Added (EVA)}

EVA is a value-based performance metric tool used to compute the true economic profit of a firm, as opposed to its accounting profit (such as net income). EVA is not a new concept. In fact, the concept of economic profit goes back to at least 1890 when Alfred Marshall wrote: "What remains of his [the owner or manager's] profits after deducting interest on his capital at the current rate may be called his earnings of undertaking or management." (Marshall, 1890) Thus, the value created by a firm (the economic profit) must reflect not only its accounting expenses, but also the opportunity cost of the capital used.

EVA is computed as follows:

$$
\text { EVA }=\text { NOPAT }-(\text { Invested Capital } x \text { Weighted Average Cost of Capital })
$$

Where:

- $\quad$ NOPAT (Net Operating Profit After Tax ) = Net Sales - Operating Expenses - Taxes

- $\quad$ Invested Capital $=$ Debt + Preferred Stock + Common Equity

When EVA is positive, then management has created value. When EVA is negative, then management has destroyed value. To maximize shareholder value, managers need to maximize EVA.

EVA was pioneered by the consulting firm Stern Stewart \& Co (Stewart, 1991; Stewart, 1994; Stern Stewart 1994). It has become a leading concept in corporate finance and a popular tool among chief financial officers since the 1990s. Stern Stewart claims to have 
worked with over 300 companies to help them become "EVA companies." Among these companies are Coca Cola, Eli Lilly, Sprint, US Postal Service, Germany’s Siemens, and Australia's Telstra. (Stern Stewart web site, October 2004).

In addition to being a performance measurement tool, EVA has also been used for setting organizational targets, compensation plans, capital budgeting goals, and corporate valuation. In fact, one of the most important uses of EVA is to align management and shareholder interests by tying executive compensation to shareholder value created (Birchard, 1994; Stern, Stewart, and Chew, 1995; Blair, 1997; Wallace, 1997; Ehrbar, 1999; Dodd and Johns, 1999; Baum, Sarver, and Strickland, 2004). EVA, thus, directly addresses the two factors motivating franchising: agency problem and capital scarcity.

\section{Market Value Added (MVA)}

MVA measures the market value that a firm has created. MVA is an extension of EVA in that MVA is equal to the present value of the future streams of EVAs. MVA compares the value of what shareholders put into the firm and what it is currently worth. When the value of management's actions and investments is more than the value of the capital contributed to the firm by shareholders, then MVA is positive and value has been created. When the reverse is true, then MVA is negative and value has been destroyed. To maximize shareholder value, management needs to maximize MVA. 
MVA is computed as follows:

$$
\text { MVA }=\text { Market Value }- \text { Common Equity }
$$

Where:

- $\quad$ Market Value $=$ Stock price $\mathrm{x}$ Shares outstanding

MVA has recently acquired more importance as EVA has come under attack for, among other things, a lack of conclusive empirical support of the relationship between shareholder value and a firm's EVA (Biddle, Bowen, and Wallace, 1997; Chen and Dodd, 1997; Chen and Dodd, 2001). CFO magazine now publishes a yearly ranking of US public corporations by MVA (GE, Microsoft, and Wal-Mart were, not surprisingly, the top 3 in 2002. McDonald's at number 75 and Cendant Corp. at number 140 were the top franchising firms (CFO Magazine, July 1, 2003)).

\section{DATA AND RESULTS}

In order to determine which restaurant firms would be included in the current study, stock, income statement and balance sheet data were obtained from Standard and Poors' COMPUSTAT database for the 10-year period 1993-2002. The study sample was arrived at through a process of elimination using several filters. Only food services firms were included (NAICS=7221 - "Full Service Restaurants," and NAICS=7222 "Limited Service Eating Places"). In 2002, there were 81 such firms in the COMPUSTAT database. Firms with less than ten years of data (1993 to 2002) were 
dropped. Forty six firms were left in the data sample. These firms were then divided into two categories: franchisors and non-franchisors. The determination of the franchising status of the firms was based on data from the International Franchise Association and Entrepreneur Magazine. Following Alon et al. (2004), four firms were dropped from the sample as they had absolute values of ROE in excess of 50 percent. Also, in order to avoid biased results, McDonald's, the largest firm in the sample, was dropped as its MVA and EVA numbers were far greater than those of any other firm in the sample (McDonald's had an average MVA of \$24.4 billion while the next highest firm had an MVA of $\$ 1.4$ billion). Forty one firms were left in the sample: 24 franchisors and 17 non-franchisors (see Appendix A).

MVA and EVA were then computed for each of these companies, and ten year averages were obtained. $95.8 \%$ of the franchisors created market value vs. $88.2 \%$ of the nonfranchisors (see Table 1). Also, $62.5 \%$ of the franchisors created economic value vs. $58.8 \%$ of the non-franchisors (see Table 2).

Table 1. Market Value Creation

\begin{tabular}{|l|c|c|}
\hline & $\begin{array}{c}\text { FRANCHISORS } \\
(\mathrm{N}=24)\end{array}$ & $\begin{array}{c}\text { NON-FRANCHISORS } \\
(\mathrm{N}=17)\end{array}$ \\
\hline $\begin{array}{l}\text { \# Companies that created } \\
\text { Market Value (MVA }>0)\end{array}$ & 23 & 15 \\
\hline $\begin{array}{l}\text { \# Companies that destroyed } \\
\text { Market Value (MVA }<0)\end{array}$ & 1 & 2 \\
\hline $\begin{array}{l}\text { Percentage of companies } \\
\text { that created Market Value }\end{array}$ & $95.8 \%$ & $88.2 \%$ \\
\hline
\end{tabular}


Table 2. Economic Value Creation

\begin{tabular}{|l|c|c|}
\hline & $\begin{array}{c}\text { FRANCHISORS } \\
(\mathrm{N}=24)\end{array}$ & $\begin{array}{c}\text { NON-FRANCHISORS } \\
(\mathrm{N}=17)\end{array}$ \\
\hline $\begin{array}{l}\text { \# Companies that created } \\
\text { Economic Value (EVA }>0)\end{array}$ & 15 & 10 \\
\hline $\begin{array}{l}\text { \# Companies that destroyed } \\
\text { Economic Value (MVA }<0)\end{array}$ & 9 & 7 \\
\hline $\begin{array}{l}\text { Percentage of companies that } \\
\text { created Economic Value }\end{array}$ & $62.5 \%$ & $58.8 \%$ \\
\hline
\end{tabular}

Average ROE and total shareholder return (computed as share price x number of shares outstanding + total dividends) were then computed for comparison purposes. Descriptive statistics are shown for the franchisors (Table 3) and for the non-franchisors (Table 4). The MVA mean is $\$ 363.4 \mathrm{M}$ (S.D. $=\$ 464.5 \mathrm{M}$ ) for the franchisors, and $\$ 144.3 \mathrm{M}$ $(\mathrm{S} . \mathrm{D} .=\$ 220.5 \mathrm{M})$ for the non-franchisors. The EVA means is $\$ 13.3 \mathrm{M}(\mathrm{S} . \mathrm{D} .=\$ 24.5 \mathrm{M})$ for the franchisors, and $\$ 3.2 \mathrm{M}(\mathrm{S} . \mathrm{D} .=\$ 13.3 \mathrm{M})$ for the non-franchisors. On average, a franchisor created $\$ 363.4 \mathrm{M}$ in market value and $\$ 13.3 \mathrm{M}$ in economic value, while a nonfranchisor created $\$ 144.3 \mathrm{M}$ in market value and $\$ 3.2 \mathrm{M}$ in economic value. Also, on average, franchisors had shareholder returns (SR) of 4.2 percent versus 0.6 percent for non-franchisors.

Table 3. Descriptive Statistics - Franchisors

\begin{tabular}{|c|c|c|c|c|}
\hline $\mathrm{N}=24$ & MVA & EVA & $\begin{array}{c}\text { Shareholder } \\
\text { Returns }\end{array}$ & ROE \\
\hline Mean & $\$ 363.4 \mathrm{M}$ & $\$ 13.3 \mathrm{M}$ & $4.2 \%$ & $4.1 \%$ \\
\hline Standard & $\$ 464.5 \mathrm{M}$ & $\$ 24.5 \mathrm{M}$ & $10.9 \%$ & $13.9 \%$ \\
Deviation & & & & \\
\hline Range & $-\$ 5.9 \mathrm{M} \rightarrow$ & $-\$ 23.0 \rightarrow$ & $-18.8 \% \rightarrow$ & $-28.5 \% \rightarrow$ \\
& $\$ 1,409.1 \mathrm{M}$ & $\$ 72.1 \mathrm{M}$ & $28.0 \%$ & $18.3 \%$ \\
\hline
\end{tabular}


Table 4. Descriptive Statistics - Non-Franchisors

\begin{tabular}{|c|c|c|c|c|}
\hline $\mathrm{N}=17$ & MVA & EVA & $\begin{array}{c}\text { Shareholder } \\
\text { Returns }\end{array}$ & ROE \\
\hline Mean & $\$ 144.3 \mathrm{M}$ & $\$ 3.2 \mathrm{M}$ & $0.6 \%$ & $4.6 \%$ \\
\hline $\begin{array}{c}\text { Standard } \\
\text { Deviation }\end{array}$ & $\$ 220.5 \mathrm{M}$ & $\$ 13.3 \mathrm{M}$ & $15.9 \%$ & $16.9 \%$ \\
\hline Range & $-\$ 3.4 \mathrm{M} \rightarrow \$ 766.2 \mathrm{M}$ & $-\$ 22.0 \rightarrow$ & $\begin{array}{c}-20.1 \% \rightarrow \\
28.3 \%\end{array}$ & $\begin{array}{c}-32.8 \% \rightarrow \\
41.2 \%\end{array}$ \\
\hline
\end{tabular}

Table 5 shows the correlation matrix. Both MVA and EVA show some correlation with the Franchise variable (0.277 and 0.247, respectively). Confirming Alon et al. (2004) results, the ROE has a very low correlation with the Franchise variable (-0.016). As expected, EVA and MVA are highly correlated (0.886). Also, ROE is correlated with EVA (0.525). This is to be expected. To see this, we can rewrite EVA as follows:

$\mathrm{EVA}=($ Equity capital $) \times(\mathrm{ROE}-$ Cost of equity capital $)$

ROE, then, is a determinant of EVA. The other determinants are risk (as reflected by the cost of capital) and the amount of equity capital used.

Table 5. Correlation Matrix

\begin{tabular}{|c|c|c|c|c|c|}
\hline & Franchise & MVA & EVA & SR & ROE \\
\hline Franchise & 1.000 & & & & \\
\hline MVA & 0.277 & 1.000 & & & \\
\hline EVA & 0.247 & 0.886 & 1.000 & & \\
\hline SR & 0.137 & 0.297 & 0.311 & 1.000 & \\
\hline ROE & -0.016 & 0.376 & 0.525 & 0.582 & 1.000 \\
\hline
\end{tabular}


To further determine that performance differed between franchisors and non-franchisors, we ran tests for equality of means. These are t-tests on the difference between the variable means of the franchisors and the non-franchisors. Table 6 displays the results. For ROE and shareholder returns, the p-values are 0.92 and 0.39 respectively, clearly showing that the differences in the means of these variables for franchisors and nonfranchisors are not significant. For MVA and EVA, the p-values are 0.08 and 0.12 respectively, much lower than for ROE and shareholder returns. However, at a 5 percent cut-off level, the means differences are not significant.

Table 6. Tests of Equality of Means

\begin{tabular}{|c|c|c|c|}
\hline Performance Metric & $\begin{array}{c}\text { Mean } \\
\text { Difference }\end{array}$ & t-value & p-value \\
\hline MVA & $\$ 219.1 \mathrm{M}$ & 1.801 & 0.079 \\
\hline EVA & $\$ 10.1 \mathrm{M}$ & 1.591 & 0.118 \\
\hline ROE & $-0.49 \%$ & 0.102 & 0.919 \\
\hline Shareholder Returns & $3.6 \%$ & 0.862 & 0.394 \\
\hline
\end{tabular}

\section{CONCLUSIONS, LIMITATIONS AND RECOMMENDATIONS FOR FUTURE RESEARCH}

The dominant theories explaining the franchising phenomenon imply that firms choosing to expand through franchising may have significant advantages over firms that grow through their own means. Franchising firms minimize agency problems, and have access to cheaper capital, motivated managerial expertise, and better local market knowledge. It can then be hypothesized that these advantages should translate into superior financial performance for the franchising firms. This study has provided some support for this 
hypothesis. It has uncovered some evidence that over the ten year period 1993-2002, US public restaurant franchisors have created more value than their non-franchising competitors:

1. Franchisors have a slightly higher propensity to create market value and economic value than non-franchisors;

2. Franchisors generate on average higher MVA and EVA than do non-franchisors; and 3. There is some correlation between Franchising and MVA and EVA.

This study has a number of limitations. First, the firms included in this study are all mature, well established firms, with at least ten years of existence as publicly traded companies. For these firms, the advantages that franchising brings are not as critical as for new, expanding firms. For example, for most of these firms, access to capital is not a serious problem. The results of this study may lead one to speculate that new, fast growing franchising firms may create more (possibly significantly more) value than nonfranchising firms at the same stage of growth. This would be an interesting hypothesis to investigate.

Second, for the reasons explained earlier, this study had a narrow focus on the US restaurant sector. Studies focusing on other sectors of the economy and on other countries could provide additional evidence on the value creation performance of franchising. 
Finally, because the focus of this study was very narrow, the sample size was small (41 firms). Expanding the sector under investigation will increase the sample size, and may lead to more robust results. 
APPENDIX A

\section{FRANCHISORS}

\begin{tabular}{ll} 
SYMBOL & COMPANY NAME \\
\hline APPB & APPLEBEES INTL INC \\
BNHNA & BENIHANA INC -CL A \\
BYBI & BACK YARD BURGERS INC \\
CEC & CEC ENTERTAINMENT INC \\
CHKR & CHECKERS DRIVE-IN RESTAURANT \\
CKR & CKE RESTAURANTS INC \\
DRI & DARDEN RESTAURANTS INC \\
EAT & BRINKER INTL INC \\
FRS & FRISCH'S RESTAURANTS INC \\
GRIL & GRILL CONCEPTS INC \\
GTIM & GOOD TIMES RESTAURANTS INC \\
JBX & JACK IN THE BOX INC \\
MAIN & MAIN STREET RESTAURANT GROUP \\
MAXE & MAX \& ERMAS RESTAURANTS \\
NATH & NATHANS FAMOUS INC \\
OSI & OUTBACK STEAKHOUSE INC \\
PNRA & PANERA BREAD CO \\
PZZA & PAPA JOHNS INTERNATIONAL INC \\
RARE & RARE HOSPITALITY INTL INC \\
RI & RUBY TUESDAY INC \\
RYAN & RYAN'S RESTAURANT GROUP INC \\
SONC & SONIC CORP \\
SZ & WORLDWIDE RESTAURANT CONCEPT \\
WEN & WENDY'S INTERNATIONAL INC \\
&
\end{tabular}

\section{NON-FRANCHISORS}

$\begin{array}{rlll} & \text { SYMBOL } & & \text { COMPANY NAME } \\ 2 & \text { ARKR } & & \text { ARK RESTAURANTS CORP } \\ 2 & \text { BOBE } & & \text { BOB EVANS FARMS } \\ 3 & \text { CAKE } & & \text { CHEESECAKE FACTORY INC } \\ 4 & \text { CBRL } & & \text { CBRL GROUP INC } \\ 5 & \text { CHUX } & \text { O CHARLEYS INC } \\ 6 & \text { ELMS } & & \text { ELMERS RESTAURANTS INC } \\ 7 & \text { ELXS } & \text { ELXSI CORP } \\ 8 & \text { JAX } & \text { J ALEXANDER CORP } \\ 9 & \text { LNY } & \text { LANDRYS RESTAURANTS INC } \\ 10 & \text { LUB } & \text { LUBYS INC } \\ 11 & \text { MHG } & \text { MERITAGE HOSPITALITY GROUP } \\ 12 & \text { MR } & \text { MORGANS FOODS INC } \\ 13 & \text { PICZQ } & \text { PICCADILLY CAFETERIAS INC } \\ 14 & \text { QDIN } & \text { QUALITY DINING INC } \\ 15 & \text { SALD } & \text { FRESH CHOICE INC } \\ 16 & \text { SNS } & \text { STEAK N SHAKE CO } \\ 17 & \text { STAR } & \text { LONE STAR STEAKHOUSE SALOON }\end{array}$




\section{BIBLIOGRAPHY}

Abden, A. M. and Haight, G. T. 2000. A Fresh Look at Economic Value Added: Empirical Study of the Fortune Five-Hundred Companies. The Journal of Applied Business Research, Volume 18, Number 2.

Alon, I. 1999. The Internationalization of US franchising Systems, New York: Garland Publishing.

Alon, I., Drtina, R. and Gilbert, J. P. 2004. The Impact of Franchising on the Returns on Equity Chains in the Restaurant Sector, Proceedings of the Annual International Society of Franchising Conference, Las Vegas, NV, March 6-7.

Baum, C. L., Sarver, L. and Strickland, T. 2004. EVA, MVA and CEO Compensation: Further Evidence. American Business Review, June, 82-87.

Biddle, G. C., Bowen, R. M., and Wallace, J. S. 1997. Does EVA Beat Earnings? Evidence on Associations with Stock Returns and Firm Values. Journal of Accounting \& Economics, Dec 31, 1997, 301-336.

Birchard, B. 1994. Mastering the New Metrics. CFO, October, 30-38.

Blair, A. 1997. Watching the New Metrics. Management Today, April, 48-50.

Bradash, J. L. 1997. Using the Plural Form in the Management of Restaurant Chains. Administrative Science Quarterly, Vol. 42, No. 2, pp. 276-303.

Brickley, J. and Dark, F. 1987. The Choice of Organizational Form: The Case of Franchising. Journal of Financial Economics, 18: 401-420.

Brigham, E. F. and Houston, J. F. 2004. Fundamentals of Financial Management, $4^{\text {th }}$ Edition, Thomson South-Western.

Bruton, G. D.; Keels, J. K. and Scifres; E. L. 2002. Corporate Restructuring and Performance: An Agency Theory Perspective on the Complete Buyout Cycle, Journal of Business Research, Vol. 55, Issue 9, September, 709-724.

Henry, D. 2004. Fuzzy Numbers. BusinessWeek, 2004, , October 4, 78-88.

Carney, M. and Gedajlovic, E. 1991. Vertical Integration in Franchise Systems: Agency Theory and Resources Explanations. Strategic Management Journal, 12: 607-629.

Caves, R. and Murphy, W. 1976. Franchising: Firms, Markets and Intangible Assets. Southern Economic Journal, 42: 572-586. 
Chen, S. and Dodd, J. L. 1997. Economic Value Added: An Empirical Examination of a New Performance Measure. Journal of Managerial Issues, Fall 1997, 318-333.

Chen, S. and Dodd, J. L. 2001. Operating Income, Residual Income and EVA: Which Metric Is More Relevant. Journal of Managerial Issues, Vol. 13, 65-86.

Collins, J. 2001. Good to Great. Harper Collins Publishers.

Combs, J. G. and Kitchen, D. J. 1999a. Can Capital Scarcity Help Agency Theory Explain Franchising? Revisiting the Capital Scarcity Hypothesis. Academic

Management Journal, 42, 196-207.

Combs, J. G. and Kitchen, D. J. 1999b. Explaining Interfirm Cooperation and Performance: Toward a Reconciliation of Predictions from the Resource-Based View and Organizational Economics. Strategic Management Journal, 20, 867-888.

Dant, R. P., Paswan A. K., and Stanworth, J. 1996. Ownership Redirection Trends in Franchising: A Cross-Sectional Investigation. International Journal of Entrepreneurial Behavior and Research, 2 (3), 48-67.

Dant, R. P., Paswan A. K., and Kaufmann, P. J. 1996. What We Know About Ownership Redirection in Franchising: A Meta-Analysis. Journal of Retailing, 72 (4), 429-44.

Dant, R. P. and Kaufmann, P. J. 2003. Structural and Strategic Dynamics in Franchising. Journal of Retailing, Vol. 79 (2), 63-75.

Dodd, J. and Johns, J. 1999. EVA Reconsidered. Business and Economics Review, 45, 13-18.

Ehrbar, A. 1999. Using EVA to Measure Performance and Assess Strategy. Strategy and Leadership, 27, 20-24.

Eisenhardt, K. 1989. Agency Theory: An Assessment and Review. Academy of Management Review, 14 (1): 57-74.

Elango, B and Fried, V. H. 1997. Franchising Research: A Literature Review and Syhthesis. Journal of Small Business Management, 35 (3), 68-81.

Fama, E. F. and Jensen, M. C. 1983. Agency Problems and Residual Claims. Journal of Law and Economics, 26, 327-350

House Committee on Small Business, 1990. Franchising in the US Economy: Prospects and Problems. In House of Representatives, $101^{\text {st }}$ Congress, $2^{\text {nd }}$ Session. Washington, DC: US Government Printing Office. 
Jensen, M. C. and Meckling, W. H. 1976. Theory of the Firm, Managerial Behavior, Agency Costs, and Ownership Structure. Journal of Financial Economics, October, 305-360.

Justis, R. T. and Judd, R. J. 2003. Franchising, $3^{\text {rd }}$ Edition, Thompson Custom Publishing.

Kostecka, A. 1987. Franchising in the Economy, 1985-1987. US Department of Commerce (Washington, DC: US Government Printing Office).

Lafontaine, F. 1992. Agency Theory and Franchising: Some Empirical Results. Rand Journal of Economics, 23(2): 263-283.

Leleux, B. F.; Spinelli, S., Jr. and Birley, S. 2003. An Analysis of Shareholder Return in Public Franchisor Companies. The Journal of Private Equity, Vol 6, No. 3.

Marshall, A. 1890. Principles of Economics, Vol. 1, New York: MacMillan \& Co.

Matheson, G. and Winter, R. 1985. The Economics of Franchise Contracts. Journal of Law and Political Economy, 28, 503-526.

Michael, S. C. 2002. Can a Franchise Chain Coordinate? Journal of Business Venturing, 17, 325-341.

Minkler, L. P. 1990. An Empirical Analysis of a Firm's Decision to Franchise. Economic Letters, 34, 77-82.

Norton, S. 1988. An Empirical Look at Franchising as an Organizational Form. Journal of Business, 61(2): 197-218.

Organization for Economic Co-Operation and Development, 1998. Corporate Governance: Improving Competitiveness and Access to Capital in Global Markets. Business Sector Advisory Group on Corporate Governance.

Oxenfeldt, A. R. and Kelly, A. O. 1968. Will Successful Systems Ultimately Become Wholly-Owned Chains? Journal of Retailing, 44 (49), 69-83.

Paulo, S. 2002. Operating Income, Residual Income and EVA: Which Metric Is More Relevant - A Comment. Journal of Managerial Issues, Vol. 14 (4), 500-506

PriceWarerhouseCoopers, 2004. Economic Impact of Franchised Businesses. A Study for the International Franchise Association Educational Foundation.

Rubin, P. 1978. The Theory of the Firm and the Structure of the Franchise Contract . Journal of Law and Economics, 21: 223-233. 
Shane, S. A. 1996. Hybrid Organizational Arrangements and Their Implications for Firm Growth and Survival: A Study of New Franchisors. Academy of Management Journal, Vol. 39, No. 1, pp. 216-234

Stewart, G. B. III. 1991. The Quest for Value. Harper Collins Publishers, Inc.

Stewart, G. B. III. 1999. EVA: Fact and Fantasy. Journal of Applied Corporate Finance, Summer, 7 (2), pp. 71-84.

Stern, Stewart. 1994. EVA Roundtable. Journal of Applied Corporate Finance, Summer, 7 (2), pp. 46-70.

Stern, J. M., Stewart, G. B. and Chew D. H. 1995. The EVA Financial System. Journal of Applied Corporate Finance, 8 (2), 32-46.

Taub, S. 2003. CFO Magazine, "MVPs of MVA.” July 1.

Tikoo, S. 1996. Assessing the Franchise Option. Business Horizons, May-June. 78-82.

Wallace, J. S. 1997. Adopting Residual Income-Based Compensation Plans: Do You Get What You Pay For? Journal of Accounting and Economics, 24 (3), 275-300. 